Mеталлофиз. новейшие технол. / Metallofiz. Noveishie Tekhnol. (C) 2014 ИМФ (Институт металлофизики 2014 , т. 36, № 2, сс. $175-188$

Оттиски доступны непосредственно от издателя

им. Г. В. Курдюмова НАН Украины)

Фотокопирование разрешено только

Напечатано в Украине.

в соответствии с лицензией

PACS numbers: 61.72.sd, 64.70.dg, 64.75.Bc, 81.05.Bx, 81.70.Jb, 82.80.Fk

\title{
Effect of Oxygen Activity on the Effectiveness of Nodulization in the Spheroidal Graphite Cast Iron Production
}

\author{
Iva Nová and Jiří Machuta
}

Technical University of Liberec,

Studentska, $1402 / 2$,

46117 Liberec 1, Czech Republic

Production of castings with spheroidal graphite iron (SGI) requires the maintenance of metallurgical and technological principles. Oxygen plays an important role in this production. The influence of oxygen on cast iron has the most significant effect on oxygen bound in oxides. Under operating conditions, it is necessary to monitor the chemical composition and temperature of the melt together with other factors, which contribute to the effect of oxygen activity and effective modifications. Influence of an applied modifier (nodulizer) of oxygen activity on the production of spheroidal graphite cast iron is established.

Виробництво відливок з чавуна з кулястим графітом потребує дотримання металургійних і технологічних принципів. Кисень відіграє важливу роль в цьому виробництві. Найбільший вплив він здійснює на кисень, зв'язаний в окислах. В умовах виробництва необхідно слідкувати за хімічним складом і температурою розплаву разом 3 іншими факторами, які дають внесок в активність кисню та ефективні модифікації. Встановлено вплив застосованого модифікатора (Іранулятора) активності кисню на виробництво чавуна з кулястим графітом.

Производство отливок из чугуна с шаровидным графитом требует соблюдения металлургических и технологических принципов. Кислород играет важную роль в этом производстве. Наибольшее влияние он оказывает на кислород, связанный в окислах. В условиях производства необходимо следить за химическим составом и температурой расплава вместе с другими факторами, которые вносят вклад в активность кислорода и эффективные модификации. Установлено влияние применяемого модификатора (гранулятора) активности кислорода на производство чугуна с шаровидным графитом.

Key words: spheroidal graphite, cast iron, nodulization, solubility, saturation, melt. 


\section{INTRODUCTION}

Now much attention is paid to the production of castings with spheroidal graphite iron (SGI), the required mechanical properties and structure, without internal defects. Cast iron production quality is closely linked with metallurgical and technological principles (suitable type of furnace, the correct batch method, melting furnace and patterns among metallurgy-inoculation or modification-nodulization). In addition to these known principles, oxygen in melt cast iron plays quite important role in the production. First oxygen was observed in cast iron in accordance with the emergence of a variety of defects, later proved to have considerable importance in the creation of embryos for the growth of graphite. The influence of oxygen on cast iron has the most significant effect on oxygen bound in oxides. Oxygen dissolved in the melt has not yet received so much attention in recent years. Hence, considerable importance of the monitoring of oxygen activity in the melt is obvious.

The value of oxygen activity can be an important criterion for checking the properties of the liquid metal, especially the quality of a modification process. Under operating conditions, it is necessary to monitor the chemical composition and temperature of the melt together with other factors that contribute to the effect of oxygen activity and effective modifications. The Department of Engineering Technology of Engineering Faculty of the Technical University of Liberec (Czech Republic) is engaged in monitoring of oxygen activity in molten iron for several years. Influence of an applied modifier (nodulizer) of oxygen activity on the production of spheroidal graphite cast iron was established.

\section{OXYGEN IN MOLTEN GRAPHITE CAST IRONS}

Oxygen is dissolved in molten iron atomically and there is a close link between one atom of oxygen and one atom of iron. At the same time, there may be complexes between $\mathrm{FeO}$ and neighbouring iron atoms of type $(\mathrm{FeO} \cdot n \mathrm{Fe})$. Oxygen gets into the molten iron from the gas phase, which is located above the molten iron. Occurrence of the oxygen in contact with the surface of molten iron leads to its dissolution in the melt iron. Physicochemical patterns of oxygen solubility in molten iron in relation to temperature were revealed by Myslivec [1]. The solubility of oxygen in molten iron behaves according to the equation:

$$
\frac{1}{2} \mathrm{O}_{2}=[\mathrm{O}]_{\mathrm{Fe}},
$$


where $[\mathrm{O}]_{\mathrm{Fe}}$ is solubility of oxygen in molten iron.

It is customary for the solubility of oxygen in molten iron to use $\left[\%\right.$ O instead of $[\mathrm{O}]_{\mathrm{Fe}}$.

The Gibbs energy change for the equation (1) can be determined by Linčevského [2], according to the equation:

$$
\Delta G_{T}^{0}=-71018-28.5 T ;
$$

here, $\Delta G_{T}^{0}$ is change of the Gibbs energy $\left(\mathrm{J} \cdot \mathrm{mol}^{-1}\right), T[\mathrm{~K}]$ is temperature.

After reaching the degree of saturation of the $\mathrm{Fe}-\mathrm{O}$ solution, oxygen begins to form a chemical compound with the iron-iron oxide $(\mathrm{FeO})$, which precipitates from the solution. The solubility of oxygen in the iron is dependent on the temperature and can be expressed by Myslivec [1] by the equation:

$$
\log [\% \mathrm{O}]=-\frac{6254}{T}+2.701 .
$$

Melts of graphite cast irons (mainly iron with spheroidal and compacted graphite) are very complex systems. It is important to use the laws of thermodynamics at their research to clarify physicochemical processes that take place during the preparation of metallurgical melt. Mutual behaviour of elements present in the melt is determined by their weight ratio and the temperature of the melt. In this regard, we are interested in the chemical reactions of elements present in the melt and further elements that we bring to the melt during processing outside the furnace. These are, in particular, such elements as carbon, silicon, magnesium, calcium, aluminium, barium, and strontium. The decisive factors of the gases in the melt cast iron are a way of melting and used melting device.

The oxygen content in the iron is present as free (dissolved) and that bound in such compounds as oxides. Hummer [3] concluded that nitrogen acts as crystallization seeds for nucleation of graphite. With increase of the oxygen content in molten iron, graphitizing effect (mainly, the action of $\mathrm{SiO}_{2}$ as graphitizing nucleus) first was reported by Hummer [4]. He certifies to the heterogeneous nucleation of $\mathrm{SiO}_{2}$ as nucleation grains for $\mathrm{SiO}_{2}$ include oxides of elements with higher affinity to oxygen ( $\mathrm{Al}, \mathrm{Ca}, \mathrm{Ba}, \mathrm{Ce})$. At higher temperatures, higher content of stable oxides $\mathrm{SiO}_{2}$ reduced carbon. Carbon oxide reduction means reducing the number of crystallization nucleuses and thus worsening graphitizing abilities of iron, which was confirmed by Hummer [3]. Šenberger [6] has found that the reduction of carbon oxides is associated with the decrease in the total oxygen content in the iron when the temperature increases. Conversely, Kusakawa [5] emphasizes that further increasing of the oxygen content considerably constitutes carbides. 


\section{ACTIVITY OF OXIDE IN CAST IRONS}

The total amount of oxygen in the cast iron is the sum of the oxygen bound in chemical compounds and free oxygen. Free oxygen becomes metallurgically active oxygen monitor of its concentration, respectively, as active concentration-activity. The activity of oxygen in the iron melt in the presence of elements with high affinity to oxygen $(\mathrm{C}, \mathrm{Si}$, respectively $\mathrm{Mg}$ in SGI) is relatively low ranging in the order of tenths of ppm units.

Oxygen activity in modified cast iron (CGI and SGI) is observed especially to verify the effectiveness of the process of modification of the melt prior to casting. It is generally known that to achieve the required effect of modification, sufficient amount of modifier (for us usually, magnesium, and abroad, cerium) must be dissolved in the melt iron There is a balance between the amount of dissolved magnesium and oxygen in the molten iron. Accordingly, the efficiency of the modification can be monitored by the amount of dissolved magnesium and oxygen activity. Monitoring properties of melt iron and measurement of oxygen activity were investigated by a team of authors [7]. For CGI at certain temperatures, the following values of melt oxygen activity were obtained: for the temperature of $1300^{\circ} \mathrm{C}, a_{\mathrm{O}}=0.19 \mathrm{ppm}$, for the temperature $1350^{\circ} \mathrm{C}, a_{\mathrm{O}}=$ $=0.16 \mathrm{ppm}$, for the temperature of $1400^{\circ} \mathrm{C}, a_{\mathrm{O}}=0.45 \mathrm{ppm}$, for the temperature of $1450^{\circ} \mathrm{C}, a_{\mathrm{O}}=0.73 \mathrm{ppm}$, for the temperature of $1480^{\circ} \mathrm{C}, a_{\mathrm{O}}=$ $=0.90 \mathrm{ppm}$. For SGI [6], the following activity values were found: at temperature of $1300^{\circ} \mathrm{C}, a_{\mathrm{O}}=0.12 \mathrm{ppm}$, at temperature of $1350^{\circ} \mathrm{C}, a_{\mathrm{O}}=$ $=0.15 \mathrm{ppm}$, at temperature of $1400^{\circ} \mathrm{C}, a_{\mathrm{O}}=0.30 \mathrm{ppm}$, at temperature of $1450^{\circ} \mathrm{C}, a_{\mathrm{O}}=0.50 \mathrm{ppm}$, at temperature of $1480^{\circ} \mathrm{C}, a_{\mathrm{O}}=0.60 \mathrm{ppm}$.

To determine the oxygen activity in molten iron, the method of measuring of electromotive voltage (EMV) on the galvanic cell is currently used, where a solid electrolyte is a refractory oxide exhibiting ionic conductivity. Reference substance with a known value of oxygen activity is used. Scheme of measuring probe for determining of the electromotive voltage is shown in Fig. 1.

Oxygen activity value can be determined by reading of EMV and temperature based on the equation, which is recommended by the probes manufacturer in the Czech Republic (Thermosondy Kladno) and have been prepared on the ČSAV, workplace Ostrava (in Czech Republic):

$$
\log \left(a_{\mathrm{O}}\right)=4.516-\{13272.4-10080(E M V+0.025)\} / T,
$$

where $T[\mathrm{~K}]$ is measured temperature of melt, $E M V[\mathrm{~V}]$ is electromotive voltage.

For foreign manufacturers CELOX probes and their contractor Heraeus Electro-Nite Company:

$$
\log a_{\mathrm{O}}=1.36+0.0059(T-1550) E M V+2 \cdot 10^{-4} \operatorname{EMV}(T-1550) .
$$




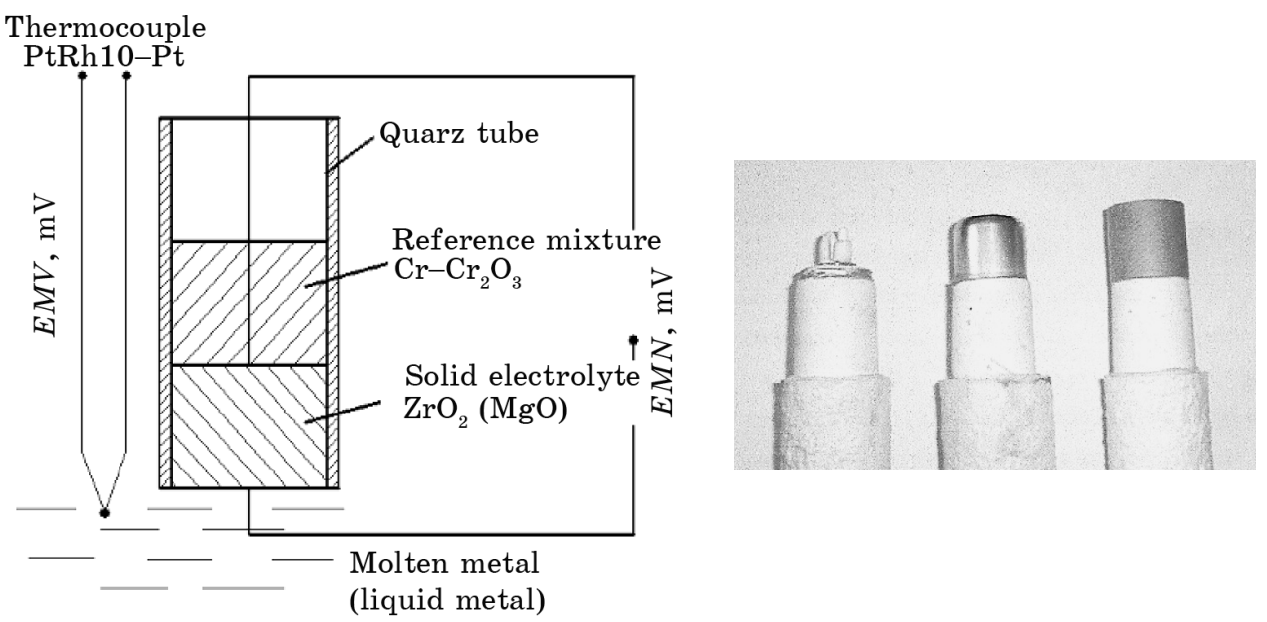

Fig. 1. Scheme of probe and probes for measuring of temperature and oxygen activity in the melt cast iron.

\section{EXPERIMENTAL OBSERVATION OF OXYGEN ACTIVITY IN THE PRODUCTION OF GRAPHITE IRON}

The aim is to investigate the oxidation at intense change of oxygen activity in cast iron with spheroidal graphite. Oxygen is intentionally added to the melt in the form of dried iron scales. For this purpose, a total of eight meltings were produced. The melting No. 8, which was made on the ground of the results of adding scale to the charge in the meltings of No. 1 to No. 7 , did not indicate the original assumptions. To the cast No. 8, $0.050 \mathrm{~kg}$ of dried flakes was added into a nodulizer (modifier) nodulization ladle and everything was covered with iron chips. The purpose of this was to determine the melt oxygen activity in the melt when the melt oxidation takes place without the establishment of equilibrium.

Trial meltings were carried out at our foundry section of engineering technology department of Technical University of Liberec. Medium frequency induction furnace IC 40 equipped with acid lining (SURACIT) produced by the Induction Ltd. company was used for melting. Maximum content of the melt in the furnace is $40 \mathrm{~kg}$. Special pig iron SORELMETAL was used as the charge material. The chemical composition of SORELMETAL is shown in Table 1 . Then $20 \mathrm{~kg}$ of pig iron with $0.25 \mathrm{~kg}$ FeSi75 were melted in induction furnace to increase silicon content.

The melt was heated in the furnace to $1450^{\circ} \mathrm{C}$ (measured by pyrometer). Modification (nodulizing) was carried out according to the SANDWICH method (i.e., in special deep foundry ladle with a cover). The ladle was also fitted with an acid lining (ACYKUP). Nodulizer 
COMPACTMAG and inoculant FeSi75 were placed on a layer of cast iron sawdust at the bottom of the pan before pouring metal. Chemical composition of the nodulizer is presented in Table 2. After nodulizing (modification), SUPERSEED inoculant was melt. Then, quartz tube sample was taken again to determine the total amount of oxygen in the melt after the nodulizing (modification) and inoculation. Chemical composition of inoculant is shown in Table 3 and the compositions of the charge for all heats are shown in Table 4. Mass scales incorporated into the individual batches are presented in Table 5 .

Preparation of the melt in the furnace was performed by a standard procedure, after heating to a temperature of $1450^{\circ} \mathrm{C}$ (measured optically uncorrected) the melt was recovered from the surface of molten slag and a sample was taken for determining the chemical composition using the quantometer (sample 'coin' was cast into a copper mould). Then, the oxygen activity was measured. After that, spill nodulizer was melt in the ladle. This ladle was also used to perform inoculant graphitizing. Again, the melt samples were used to determine the chemical composition of the produced iron.

Measurements of oxygen activity in the melt after the nodulization (modification) and inoculation were also performed (see Fig. 2). Chemical composition of cast iron melts before and after the modification were monitored by spectrometer. The obtained values are presented in

TABLE 1. Chemical composition of SORELMETAL iron.

\begin{tabular}{c|c|c|c|c|c|c}
\hline \multicolumn{7}{c}{ Content of elements, \% } \\
\hline $\mathrm{Fe}$ & $\mathrm{C}$ & $\mathrm{Si}$ & $\mathrm{Ni}$ & $\mathrm{P}$ & $\mathrm{S}$ & $\mathrm{Ni}$ \\
\hline 95.48 & 4.23 & 0.15 & 0.013 & 0.07 & 0.026 & 0.01 \\
\hline
\end{tabular}

TABLE 2. Chemical composition of the nodulizer (COMPACTMAG).

\begin{tabular}{c|c|c|c|c}
\hline \multicolumn{5}{c}{ Chemical composition, \% } \\
\hline $\mathrm{Si}$ & $\mathrm{Mg}$ & $\mathrm{KVZ}$ & $\mathrm{Ca}$ & $\mathrm{Al}$ \\
\hline $44-48$ & $5-6$ & $5-7$ & $1.8-2.3$ & $\max .1$ \\
\hline
\end{tabular}

TABLE 3. Chemical composition of the used inoculants.

\begin{tabular}{c|c|c|c|c|c}
\hline \multicolumn{7}{c}{ Chemical composition, \% } \\
\hline & Fe & $\mathrm{Si}$ & $\mathrm{Al}$ & $\mathrm{Sr}$ & $\mathrm{Ca}$ \\
\hline FeSi75 & 75 & 25 & & & \\
SUPERSEED & & 75 & $\max .0 .5$ & 0.8 & 0.1 \\
\hline
\end{tabular}


TABLE 4. Composition of charge.

\begin{tabular}{ccc}
\hline Materials & Mass of materials in furnace, $\mathrm{kg}$ \\
\hline SORELMETAL & 20 \\
FeSi75 & 0.25 \\
& Mass in ladle, $\mathrm{kg}$ & \\
FeSi75 & $0.156(1.65 \%)$ \\
SUPERSEED & $0.03(0.15 \%)$ \\
COMPACTMAG & $0.33(1.65 \%)$ \\
\hline
\end{tabular}

TABLE 5. Quantity of iron scale supplement into charge.

\begin{tabular}{c|c|c}
\hline Number of melting & $\begin{array}{c}\text { Mass scales } \\
\text { added to the charge, } \mathrm{kg}\end{array}$ & $\begin{array}{c}\text { The amount of scale } \\
\text { in batch, \% }\end{array}$ \\
\hline 1 & 0 & 0 \\
2 & 0.05 & 0.25 \\
3 & 0.08 & 0.4 \\
4 & 0.10 & 0.5 \\
5 & 0.125 & 0.625 \\
6 & 0.15 & 0.75 \\
7 & 0.20 & 1.0 \\
8 & 0.05 & 0.25 \\
\hline
\end{tabular}

Tables 6 and 7. The measured values of electromotive force in the melt prior to nodulization and after inoculation are shown in Tables 8 and 9.

Using equations (4) and (5), values of oxygen activity were calculat-

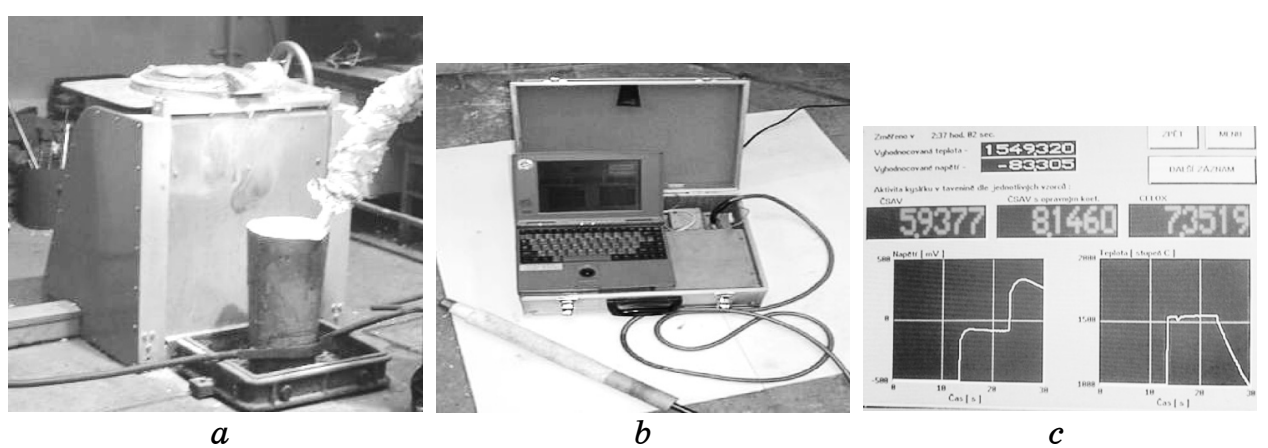

Fig. 2. Measuring of the oxygen activity: measurement of oxygen activity in ladle $(a)$, measuring equipment $(b)$, monitor measuring equipment $(c)$. 
TABLE 6. Chemical composition of melt cast iron before nodulization of melt.

\begin{tabular}{c|c|c|c|c|c}
\hline \multirow{2}{*}{$\begin{array}{c}\text { Number of } \\
\text { meeting }\end{array}$} & \multicolumn{5}{|c}{ Chemical composition, \% } \\
\cline { 2 - 6 } & $\mathrm{C}$ & $\mathrm{Si}$ & $\mathrm{P}$ & $\mathrm{Mn}$ & $\mathrm{S}$ \\
\hline 1 & 4.07 & 0.994 & 0.020 & 0.033 & 0.009 \\
2 & 3.86 & 0.952 & 0.019 & 0.031 & 0.008 \\
3 & 3.94 & 0.944 & 0.021 & 0.035 & 0.008 \\
4 & 3.95 & 0.928 & 0.018 & 0.027 & 0.008 \\
5 & 3.85 & 0.828 & 0.023 & 0.025 & 0.009 \\
6 & 3.82 & 0.887 & 0.022 & 0.030 & 0.008 \\
7 & 3.80 & 0.820 & 0.022 & 0.024 & 0.008 \\
8 & 3.97 & 1.040 & 0.019 & 0.040 & 0.009 \\
\hline
\end{tabular}

TABLE 7. Chemical composition of melt cast iron after nodulization of melt (SANDWICH).

\begin{tabular}{c|ccccccc}
\hline \multirow{2}{*}{$\begin{array}{c}\text { Number } \\
\text { of meet- } \\
\text { ing }\end{array}$} & \multicolumn{7}{|c}{ Chemical composition, \% } \\
\cline { 2 - 7 } & $\mathrm{C}$ & $\mathrm{Si}$ & $\mathrm{P}$ & $\mathrm{Mn}$ & $\mathrm{S}$ & $\mathrm{Mg}$ \\
\hline 1 & 4.05 & 2.52 & 0.019 & 0.043 & 0.009 & 0.050 \\
2 & 3.82 & 2.61 & 0.020 & 0.050 & 0.009 & 0.043 \\
3 & 3.75 & 2.74 & 0.022 & 0.052 & 0.009 & 0.045 \\
4 & 3.79 & 2.72 & 0.020 & 0.048 & 0.009 & 0.043 \\
5 & 3.82 & 2.77 & 0.022 & 0.042 & 0.008 & 0.045 \\
6 & 3.74 & 2.73 & 0.022 & 0.048 & 0.009 & 0.045 \\
7 & 3.68 & 2.75 & 0.023 & 0.041 & 0.008 & 0.038 \\
8 & 3.67 & 3.00 & 0.019 & 0.057 & 0.014 & 0.040 \\
\hline
\end{tabular}

ed, which are also listed in the relevant tables. Evaluation of the total oxygen in the melt before the nodulization and after inoculation was done using LECO TC-336 analyser. The total amount of oxygen in molten iron before and after modification is shown in Table 9. When comparing oxygen activity, oxygen activity dependence on temperature must be considered. Values of recalculated oxygen activity in the comparative temperature of $1400^{\circ} \mathrm{C}$ are given in Table 10 .

After the metallurgical treatment of the melt, i.e., after the modification (secondary metallurgy), cast was melt into prepared bentonite moulds that were used for production of testing castings $\varnothing 30 \times 150 \mathrm{~mm}$ and Y2 blocks.

The measured and corresponding calculated values were plotted as 
TABLE 8. Oxygen activity and temperature in molten iron before nodulization and inoculation.

\begin{tabular}{c|c|c|c|c|c}
\hline \multirow{2}{*}{$\begin{array}{c}\text { Number } \\
\text { of meet- } \\
\text { ing }\end{array}$} & $\begin{array}{c}\text { Temperature } \\
\text { of melt, }{ }^{\circ} \mathrm{C}\end{array}$ & $\begin{array}{c}\text { Electromotive } \\
\text { voltage, } \mathrm{mV}\end{array}$ & $\begin{array}{c}\text { Activity of oxygen, ppm } \\
\text { by equation } \\
\text { CSAV (5) }\end{array}$ & $\begin{array}{c}\text { My equation } \\
\text { CELOX (6) }\end{array}$ & $\begin{array}{c}\text { Mass of } \\
\text { celings, } \\
\mathrm{kg}\end{array}$ \\
\hline 1 & 1569 & -104 & 7.5 & 6.2 & 0 \\
2 & 1616 & -116 & 10.1 & 7.5 & 0.050 \\
3 & 1594 & -115 & 8.2 & 6.5 & 0.080 \\
4 & 1560 & -116 & 6.0 & 5.1 & 0.100 \\
5 & 1559 & -112 & 6.1 & 5.3 & 0.125 \\
6 & 1597 & -111 & 9.1 & 7.0 & 0.150 \\
7 & 1530 & -112 & 4.2 & 3.9 & 0.200 \\
8 & 1650 & -105 & 15.5 & 11.1 & 0.050 \\
\hline
\end{tabular}

TABLE 9. Oxygen activity and temperature in molten iron after nodulization and inoculation.

\begin{tabular}{c|c|c|cc|c}
\hline \multirow{2}{*}{$\begin{array}{c}\text { Number } \\
\text { of meet- } \\
\text { ing }\end{array}$} & $\begin{array}{c}\text { Temperature } \\
\text { of melt, }{ }^{\circ} \mathrm{C}\end{array}$ & $\begin{array}{c}\text { Electromotive } \\
\text { voltage, mV }\end{array}$ & $\begin{array}{c}\text { Activity of oxygen, ppm } \\
\text { vy equation } \\
\text { C.SAV (5) }\end{array}$ & $\begin{array}{c}\text { by equation } \\
\text { CELOX (6) }\end{array}$ & scalings, kg \\
\hline 1 & 1354 & -283 & 0.06 & 0.14 & 0 \\
2 & 1363 & -273 & 0.07 & 0.16 & 0.050 \\
3 & 1395 & -263 & 0.13 & 0.23 & 0.080 \\
4 & 1349 & -300 & 0.04 & 0.10 & 0.100 \\
5 & 1348 & -273 & 0.06 & 0.15 & 0.125 \\
6 & 1382 & -268 & 0.11 & 0.19 & 0.150 \\
7 & 1440 & -216 & 0.44 & 0.58 & 0.200 \\
8 & 1390 & -220 & 0.22 & 0.38 & 0.050 \\
\hline
\end{tabular}

temperature dependence of the oxygen activity of the melt before and after the nodulization; see Figs. 3 and 4.

The obtained values of oxygen activity were recalculated on the comparative activity values for comparative temperature of $1400^{\circ} \mathrm{C}$ by the equation:

$$
a_{s}=a_{n}-4.0\left[e^{0.0114 T_{\mathrm{n}}}-e^{0.0114 \times 1400}\right] 10^{-8},
$$

where $a_{s}$ is activity of oxygen by comparative temperature, $a_{n}$ is calculation activity for some temperature, $T_{n}$ is temperature of melt for cal- 
TABLE 10. Oxygen activity calculated for temperature $1400^{\circ} \mathrm{C}$.

\begin{tabular}{c|c|c|c}
\hline $\begin{array}{c}\text { Number of } \\
\text { melting }\end{array}$ & $\begin{array}{c}\text { Mass of scales } \\
\text { added to the } \\
\text { melt, kg }\end{array}$ & $\begin{array}{c}\text { Active oxygen } \\
\text { recalculated according } \\
\text { to equation (5), ppm }\end{array}$ & $\begin{array}{c}\text { Active oxygen } \\
\text { recalculated according } \\
\text { to equation (6), ppm }\end{array}$ \\
\hline 1 & 0 & 0.17 & 0.27 \\
2 & 0.050 & 0.16 & 0.26 \\
3 & 0.080 & 0.16 & 0.25 \\
4 & 0.100 & 0.17 & 0.26 \\
5 & 0.125 & 0.18 & 0.29 \\
6 & 0.150 & 0.16 & 0.25 \\
7 & 0.200 & 0.29 & 0.44 \\
8 & 0.050 & 0.25 & 0.42 \\
\hline
\end{tabular}

culation activity.

\section{METALLOGRAPHIC EVALUATION OF THE STRUCTURE AND MECHANICAL PROPERTIES}

The cast samples $\varnothing 30 \times 15 \mathrm{~mm}$ were prepared for metallographic observation by machining (using metallographic grinding paper) and then etched. For etching, Nital $3 \%$ was used. For observation of metallo-

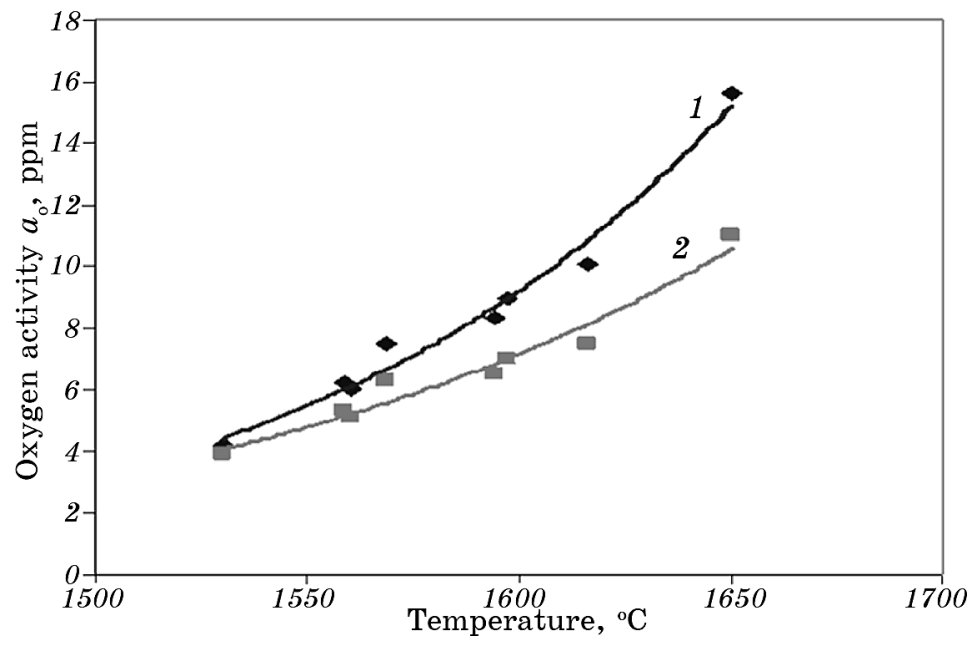

Fig. 3. Dependence of oxygen activity on temperature before nodulization (modification): 1 -according to equation ČSAV, 2-according to equation Electro-Nite. 


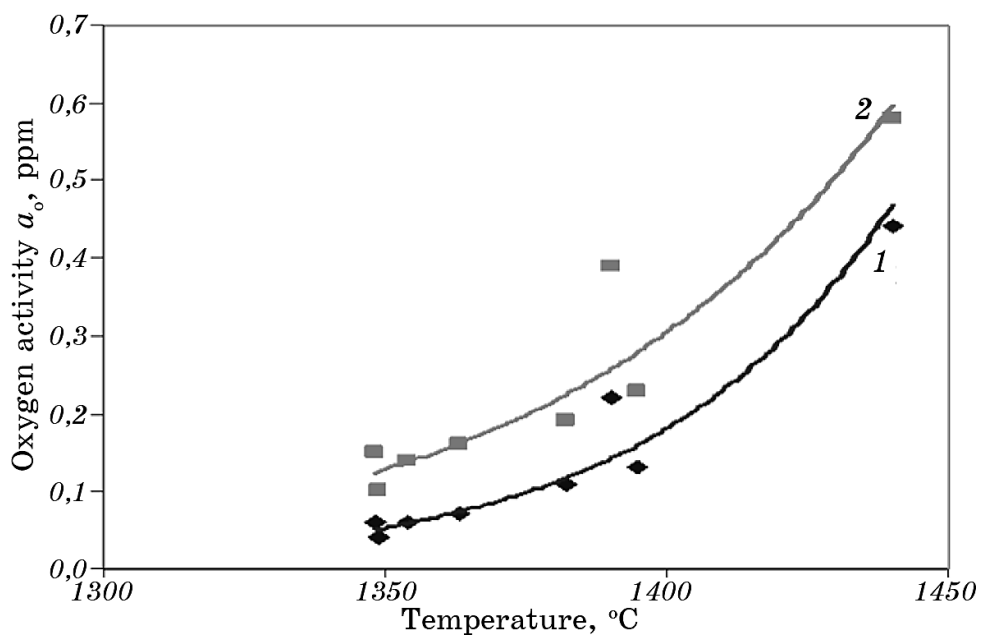

Fig. 4. Dependence of oxygen activity on temperature after nodulization (modification): 1 -according to equation ČSAV, 2-according to equation Electro-Nite.

graphic structure, NEOPHOT 21 light microscope (manufactured by Carl Zeiss Jena) was used. First, the structure was observed in the etched state in order to determine the shape, size and distribution of graphite at 100 times magnification. After etching, iron matrix was monitored. In Figure 5, the structure of the cast No. 1 to No. 8 is shown.

Microstructure of cast iron after the nodulization (modification) was evaluated according to Czech standard CSN 420461. At the same time, the number of nodules per $\mathrm{mm}^{2}$ of cast iron structure was evaluated. The observed microstructure is summarized in Table 11.

TABLE 11. Microstructure of cast iron samples.

\begin{tabular}{c|c|c}
\hline $\begin{array}{c}\text { Number } \\
\text { of melt }\end{array}$ & Microstructure for ČSN 420461 & $\begin{array}{c}\text { Number of nodules } \\
\text { per } m^{-2}\end{array}$ \\
\hline 1 & $60 \%$ VI6 + 40\% V6-P45 & 135 \\
2 & $70 \%$ VI5 + 30\% V6-P70 & 120 \\
3 & $60 \%$ VI5 + 40\% V6-P45 & 100 \\
4 & $60 \%$ VI5 + 40\% V6-P70 & 120 \\
5 & $70 \%$ VI5 + 30\% V6-P70 & 100 \\
6 & $30 \%$ VI5 + 70\% V6-P45 & 105 \\
7 & $30 \%$ VI6 + 70\% V6-P15-F15-C40-Cv 6000 & 30 \\
8 & $40 \%$ VI5 + 60\% V7-P45 & 105 \\
\hline
\end{tabular}




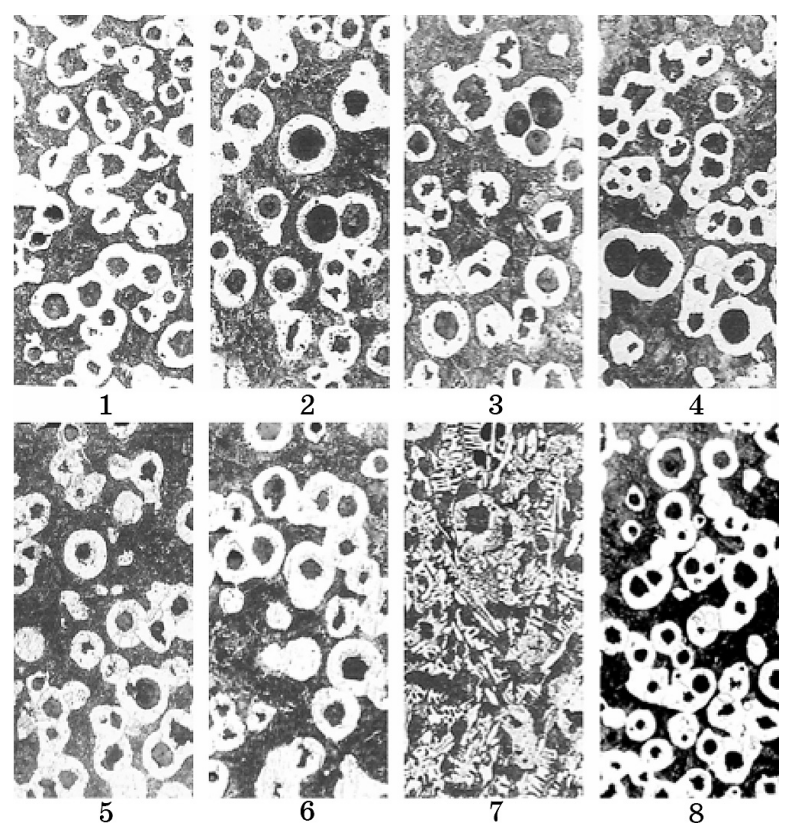

Fig. 5. Microstructure of samples, melt No. 1 to No. 8 after nodulization, $a_{\mathrm{O} 1400}$ etch-Nital $3 \%$, magnification $\times 100$.

At our department of Technical University of Liberec, long-term research on the prediction of the quality of the melt for the production of all three basic types of cast iron was conducted. Temperature dependences of the oxygen activity in melts of grey cast iron, compacted graphite iron, and spheroidal graphite iron are presented in Fig. 6. It was founded that grey cast iron (with flake graphite) at comparable melt temperature has maximum value of oxygen activity. Somewhat lower is the oxygen activity in the melt of compacted graphite iron. The lowest oxygen activity is in the melt of the spheroidal graphite iron. Oxygen activity values were calculated on the basis of the measured values of the EMV and calculated values with use of the ČSAV equation. The oxygen activity dependences on temperature of the melts in the cast irons, when the oxygen activity was calculated from the measured values of EMV using CELOX ELECTRO-NITE equation are placed in Fig. 7.

Oxygen activity in ductile iron is significantly lower than that of steel. This is caused by the higher concentration of elements that reduce the activity of oxygen $(\mathrm{C}, \mathrm{Si}, \mathrm{Mn})$. Determination of oxygen activity can provide information about the properties associated primarily with the content of elements dissolved in the melt. It is particularly important for SGI to add magnesium to the melt in a surplus. It is caused by the fact that magnesium is consumed in desulfurization and 


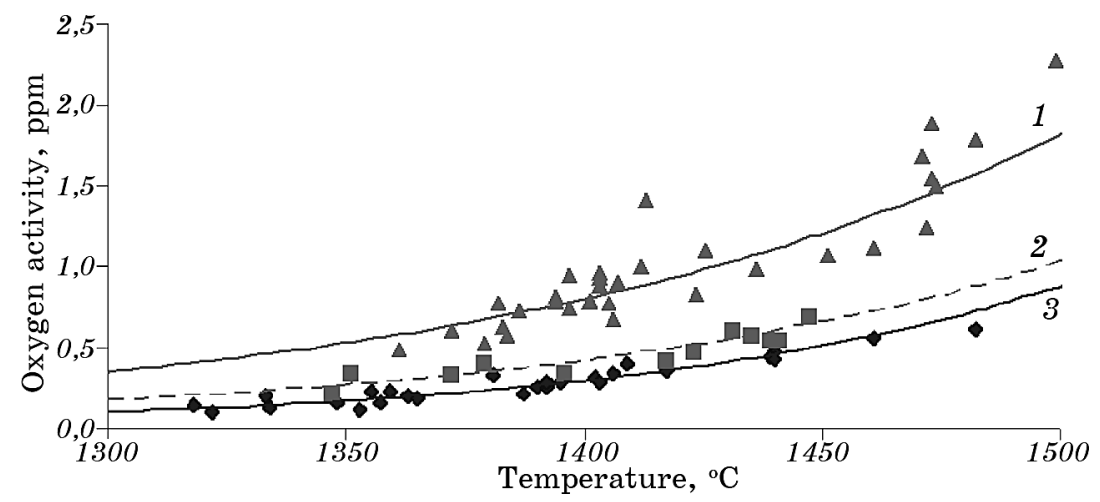

Fig. 6. Dependence of oxygen activity on temperature for GCI, CGI, and SGI melts, equation ČSAV was used for $a_{0}$ calculus [7].

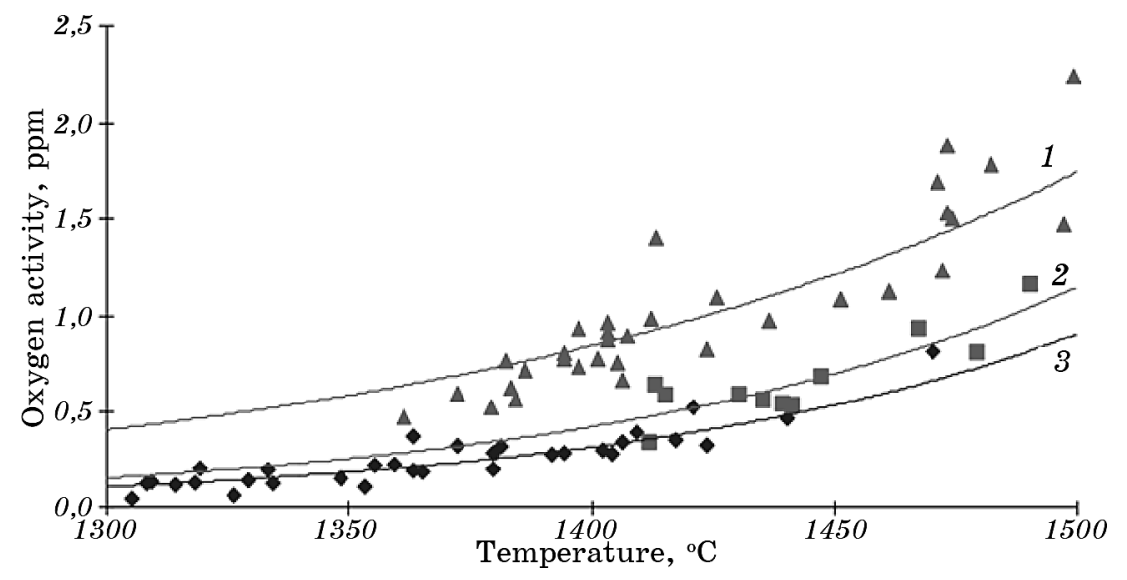

Fig. 7. Dependences of oxygen activity on temperature for GCI, CG, and SGI melts, by equation Electro-Nite was used for $a_{0}$ calculus [7].

deoxidation, and only the remaining magnesium, which is dissolved in the melt, affects the secretion of graphite. There is a relationship between the activity of oxygen and magnesium dissolved in the melt, that allows to evaluate the effectiveness of modifications by measuring oxygen activity [7].

\section{CONCLUSION}

At the moment, the value of oxygen activity is an important metallurgical parameter for determining the quality of iron melt.

The presence of iron oxides in the charge (approx. $0.75 \%$ ), respectively, iron in the melt does not increase substantially the total amount 
or activity of oxygen. Oxygen for secondary metallurgical treatment of the melt binds to magnesium and silicon. Other components and products of these reactions influence the amount of graphitizing nucleuses for the production of spheroidal graphite.

The values of oxygen activity are dependent on temperature; they increase with temperature increasing. Before modification at $1616^{\circ} \mathrm{C}$, the oxygen activity was $10.1 \mathrm{ppm}$ regardless of the $0.25 \%$ of the dried steel swarf added to furnace. Oxygen activity is of considerable importance, especially after modification. Its values are significantly lower than in the case of the presence of iron oxides in the melt iron. Converting values of oxygen activity after modification at the temperature of $1400^{\circ} \mathrm{C}$, low values of 0.16 to $0.29 \mathrm{ppm}$ were observed. Activity values of oxygen at $1400^{\circ} \mathrm{C}$ from 0.16 to $0.18 \mathrm{ppm}$ were detected after adding of $0.75 \%$ dried flakes to the melt. These values of oxygen activity correspond to ferrite-pearlite metal mass with regular granular graphite with sizes ranging from 30 to $120 \mu \mathrm{m}$. A higher value of oxygen activity after modification by $0.29 \mathrm{ppm}$ was detected by addition of $1 \%$ in the batch scale. The structure of iron is different, it consists of a small number of spheroidal graphite with a high proportion of free cementite structures equal to 420,461 which comprise $30 \%+70 \%$ VI6 V6-P15-C40-F15-Cv 6000, with a share of 30 globules to $\mathrm{mm}^{2}$.

This paper was supported by the research project SGS 2822.

\section{REFERENCES}

1. T. Myslivec, Fyzikálně Chemické Základy Ocelářství (Physico-Chemical Principles of the Steel Industry) (Prague: SNTL: 1971) (in Czech).

2. B. V. Linchevskiy, Termodinamika i Kinetika Vzaimodeystviya Gazov s Zhidkimi Metallami (Moscow: Metallurgiya: 1986) (in Russian).

3. R. Hummer, Giesserei, No. 24: 884 (1991).

4. R. Hummer, Adv. Mate. Res., 4-5: 269 (1997).

5. T. Kusakawa, Memoirs of the School of Science and Engineering, Waseda University, 52: 163 (1988).

6. J. Šenberger, Sbornik 14 Celostátni Konference (Brno: 2000), s. 34.

7. L. Konečný, J. Exner, and I. Nová, Aktivita Kysliku u Grafitických Litin (Oxygen Activity of Graphite Cast Iron) (Final Report of Grant Project GAČR 106/95/ 171 TU v Liberci: 1998) (in Czech).

8. I. Nová, J. Bradáč, M. Vrba, and J. Šmrha, Archives of Foundry Engineering, 6, No. 18: 15 (2006).

9. L. Břištala, Vliv Kysliku v Litinách s Kuličkovým Grafitem na Homogenitu Odlitku (Influence of Oxygen Activity of Spheroidal Graphite Iron on Homogeneity Castings) (Thesis, KSM-FS, TU in Liberci: 2001) (in Czech).

10. R. Knébl, Vliv Kysliku v Grafitických Litinách na Homogenitu Odlitků (Influence of Oxygen in Graphite Moulds on Castings Homogeneity) (Thesis, KSMFS, TU in Liberec: 2000) (in Czech).

11. J. Machuta and I. Nová, Metallofiz. Noveishie Tekhnol., 34, No. 7: 977 (2012). 